\title{
Primary biliary cirrhosis in a patient with Turner syndrome
}

\author{
Piotr Milkiewicz $M D^{1,2}$, Jenny Heathcote $M D^{1}$
}

P Milkiewicz, J Heathcote. Primary biliary cirrhosis in a patient with Turner syndrome. Can J Gastroenterol 2005;19(10):631-633.

\begin{abstract}
An increased prevalence of $\mathrm{X}$ chromosome monosomy has recently been demonstrated in patients with primary biliary cirrhosis (PBC). Chronic cholestasis of unknown etiology is a common clinical feature in patients with Turner syndrome who reach the fourth and fifth decades of life. A 37-year-old patient with Turner syndrome who presented with clinical and biochemical features of chronic cholestasis is described. Subsequent investigations confirmed the diagnosis of PBC. The patient did not respond to the medical treatment and was referred for liver transplant assessment. The present case may support the importance of $\mathrm{X}$ chromosome genes in the development of genetic predisposition to $\mathrm{PBC}$, and emphasizes the necessity for a systematic study of the prevalence of $\mathrm{PBC}$ in patients with Turner syndrome.
\end{abstract}

Key Words: Primary biliary cirrhosis; Turner syndrome urner syndrome (TS) is a disorder associated with complete or partial monosomy of the $\mathrm{X}$ chromosome. TS occurs in phenotypic females and presents with short stature and features secondary to gonadal dysgenesis (1). An increased prevalence of $\mathrm{X}$ chromosome monosomy in peripheral white blood cells was recently reported in patients with primary biliary cirrhosis (PBC) (2). Epidemiological reports in TS indicate an association with chronic cholestatic liver disease of unknown etiology and the risk of liver cirrhosis in patients with TS is approximately six times higher than in the general population (3). In the present report, we describe a patient who presented with both TS and PBC.

\section{CASE PRESENTATION}

A 37-year-old woman with TS diagnosed in her childhood and a history of type 2 diabetes mellitus, hysterectomy and breast implants presented in 1999 with recurrent episodes of right hypochondrial pain. She underwent cholecystectomy but her symptoms persisted, and she had an endoscopic retrograde cholangiopancreatography in 2000. Although it was normal, she underwent sphincterotomy because she was thought to possibly have biliary dyskinesia, but it did not relieve her symptoms. Her serum biochemistry at that time was as follows: aspartate aminotransferase $75 \mathrm{U} / \mathrm{L}$ (normal range $3 \mathrm{U} / \mathrm{L}$ to $30 \mathrm{U} / \mathrm{L}$ ), alanine aminotransferase $142 \mathrm{U} / \mathrm{L}$ (normal range

\section{Une cirrhose hypertrophique de Hanot- Gilbert chez un patient atteint du syndrome de Turner}

\begin{abstract}
Une augmentation de la prévalence de monosomie du chromosome $\mathrm{X}$ a récemment été démontrée chez les patients atteints de cirrhose hypertrophique de Hanot-Gilbert (CHHC). Une cholestase chronique d'étiologie inconnue est une caractéristique clinique courante chez les patients atteints du syndrome de Turner qui atteignent la trentaine ou la quarantaine. Le cas d'un patient de 37 ans atteint du syndrome de Turner présentant les caractéristiques cliniques et biochimiques de cholestase chronique est décrit. Des examens subséquents ont confirmé un diagnostic de CHHC. Le patient n'a pas réagi au traitement médicamenteux et a été orienté vers une évaluation de greffe hépatique. Ce cas pourrait étayer l'importance des gènes des chromosomes $\mathrm{X}$ pour établir la prédisposition génétique à la CHCC et souligne la nécessité de mener une étude systématique de la prévalence de CHHC chez les patients atteints du syndrome de Turner.
\end{abstract}

$3 \mathrm{U} / \mathrm{L}$ to $30 \mathrm{U} / \mathrm{L}$ ), alkaline phosphatase $345 \mathrm{U} / \mathrm{L}$ (normal range $30 \mathrm{U} / \mathrm{L}$ to $120 \mathrm{U} / \mathrm{L}$ ), bilirubin $31 \mu \mathrm{mol} / \mathrm{L}$ (normal range $3 \mu \mathrm{mol} / \mathrm{L}$ to $17 \mu \mathrm{mol} / \mathrm{L}$ ), albumin $42 \mathrm{~g} / \mathrm{L}$ (normal range $38 \mathrm{~g} / \mathrm{L}$ to $45 \mathrm{~g} / \mathrm{L}$ ), hemoglobin $126 \mathrm{~g} / \mathrm{L}$, leukocytes $0.0075 \times 10^{9} / \mathrm{L}$ (normal range $4 \times 10^{9} / \mathrm{L}$ to $11 \times 10^{9} / \mathrm{L}$ ) and platelets $284 \times 10^{9} / \mathrm{L}$ (normal range $150 \times 10^{9} / \mathrm{L}$ to $400 \times 10^{9} / \mathrm{L}$ ). She was referred to a tertiary referral liver clinic. Her major complaints were persistent right upper quadrant pain, mild pruritus, dry eyes and fatigue. On examination, she was noted to be short in stature and had other phenotypic features of TS. There were no stigmata of chronic liver disease. Laboratory investigations, apart from results mentioned above, showed a positive antimitochondrial antibody (AMA) level of $69 \mathrm{U} / \mathrm{mL}$ (determined by ELISA, normal value less than $5 \mathrm{U} / \mathrm{mL}$ ) and an elevated immunoglobulin (Ig)M of $15 \mathrm{~g} / \mathrm{L}$ (normal range $0.7 \mathrm{~g} / \mathrm{L}$ to $1.7 \mathrm{~g} / \mathrm{L})$. Antinuclear antibody, antismooth muscle antibody, $\operatorname{IgG}, \operatorname{IgA}$, ceruloplasmin and alpha-1-antitrypsin were all normal. Screening for viral hepatitis was negative, and an abdominal ultrasound was essentially normal. She underwent percutaneous liver biopsy which showed the presence of delicate septation with portal fibrous expansion and moderate (approximately $50 \%$ ) duct loss with ductular proliferation, thought to be compatible with stage 2 PBC. Bone densitometry showed osteopenia. She was prescribed ursodeoxycholic acid at a dose of $15 \mathrm{mg} / \mathrm{kg}$ body weight but her biochemistry

\footnotetext{
${ }^{1}$ Toronto Western Hospital, University Health Network, Toronto, Ontario; ${ }^{2}$ Department of Gastroenterology, Pomeranian Medical School, Unii Lubelskiej 1, Poland

Correspondence: Dr Piotr Milkiewicz, Toronto Western Hospital, University Health Network, 399 Bathurst Street, 6B Fell Pavilon, Room 172,

Toronto, Ontario M5T 2S8. Telephone 416-603-5800, fax 416-603-6281, e-mail p.milkiewicz@wp.pl

Received for publication May 11, 2005. Accepted May 11, 2005
} 
A

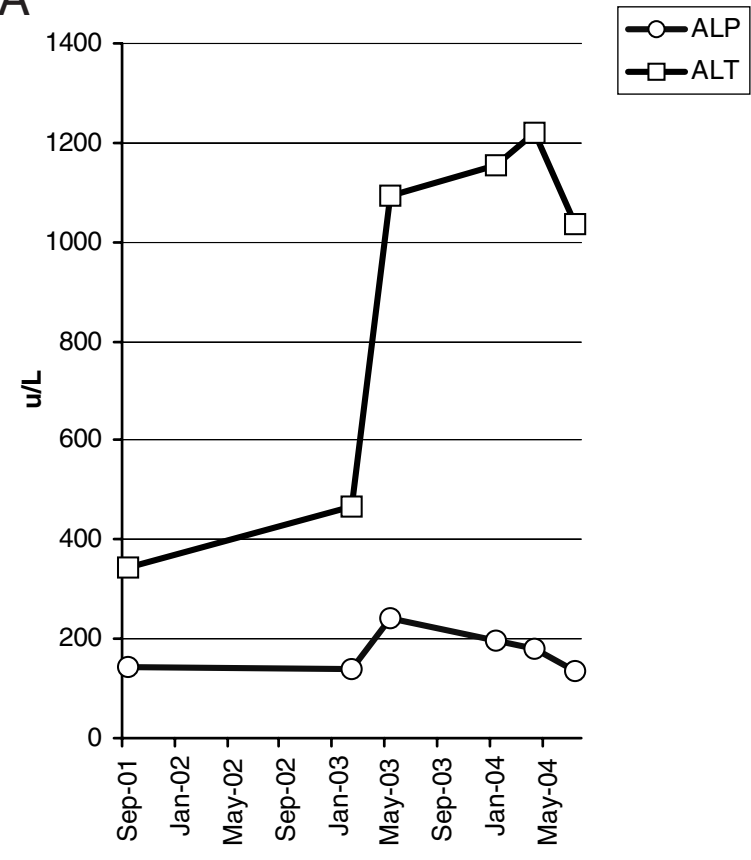

B

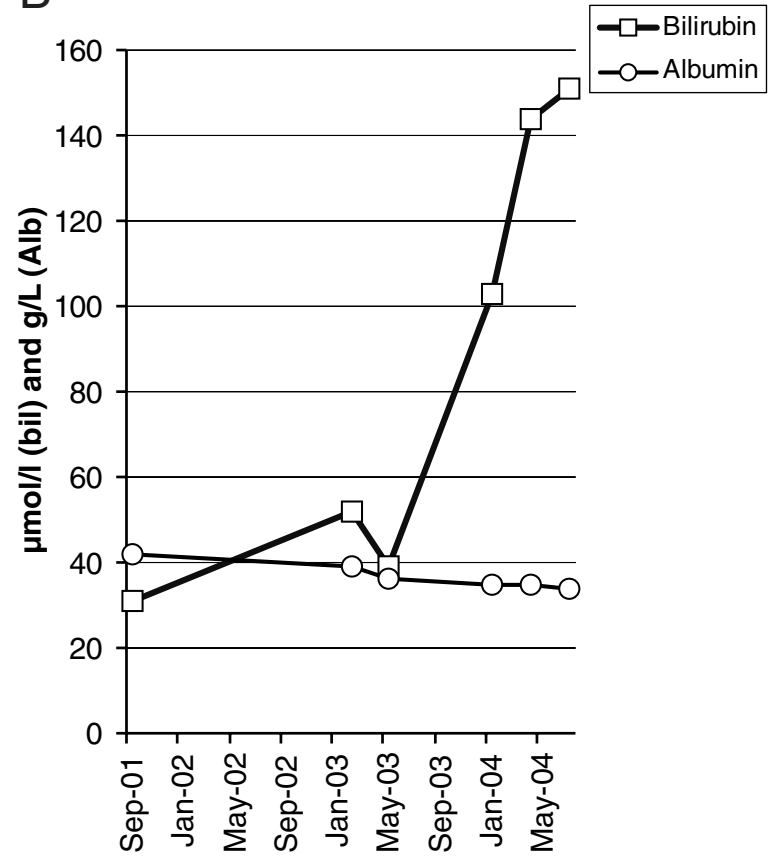

Figure 1) Liver biochemistry of described patient. A Alanine aminotransferase (ALT) (normal range 3 U/L to 30 U/L) and alkaline phosphatase (ALP) (normal range $30 \mathrm{U} / \mathrm{L}$ to $120 \mathrm{U} / \mathrm{L}$ ). B Bilirubin (normal range $3 \mu \mathrm{mol} / \mathrm{L}$ to $17 \mu \mathrm{mol} / \mathrm{L}$ ) and albumin (normal range $38 \mathrm{~g} / \mathrm{L}$ to $45 \mathrm{~g} / \mathrm{L}$ )

continued to deteriorate (Figure 1). Because she complained of progressive and disabling fatigue, she was referred for liver transplant assessment. Upper gastrointestinal endoscopy performed at that time showed features of mild portal gastropathy.

\section{DISCUSSION}

There is only one report (4) published in English language literature describing a patient with TS who also had PBC. There are two other reports on simultaneous occurrence of TS and PBC, one published in Spanish (5) and another one published in proceedings to a medical meeting (6). The prevalence of PBC in TS has never been studied, despite the fact that chronic cholestasis with elevated liver biochemistry can be observed in $80 \%$ of patients with TS over the age of 35 years (7). It has also been reported that patients with TS may have positive anti-liverkidney microsomal (LKM) antibodies (detected with indirect immunofluorescence, a method frequently associated with misinterpretation of AMA as LKM) (8). Systematic analysis of the presence of AMA has not been reported in the majority of clinical studies on patients with TS. However, TS and PBC share several similarities (9). In both disorders, cholestasis is age-related (ie, develops in older rather that younger subjects). Both conditions are strongly associated with autoimmune disorders. Antithyroid antibodies are found in approximately $40 \%$ of patients with TS and more commonly in those who also have abnormal liver biochemistry (10). Also, the risk of inflammatory bowel disease in TS, estimated to be between $2.6 \%$ and $3 \%$, is much higher than in the general population (11). Celiac disease shows a similar prevalence in both PBC and TS (12). Osteopenia, which often complicates PBC, is also associated with TS. Typically, bone mass improves but does not normalize on hormonal therapy in patients with TS; thus, estrogen deficiency cannot be considered the only responsible factor. Therefore, the presence of an unknown 'intrinsic bone defect' has been postulated to explain decreased bone mass in these patients (1). Because chronic cholestasis may contribute to abnormal bone density, its role in the development of osteopenia in TS can be contemplated. It has also been demonstrated that as many as $78 \%$ of patients with TS have bile duct changes typically seen in small duct primary sclerosing cholangitis, a disease in which histology could be difficult to differentiate from PBC (13).

If the prevalence of TS is one in 2500 (this frequently quoted proportion is probably an overestimation, because recent reports [14] have shown that prenatal diagnosis of TS leads to abortion in $71 \%$ to $100 \%$ of cases), then there should be approximately 5000 patients with TS in the province of Ontario, where we practice. Even if we saw all patients with $\mathrm{PBC}$ from our province (which is quite unrealistic) and the patient in the present study represented the only case of TS with PBC in Ontario, the calculated prevalence of PBC in TS would be 10 times higher than in the general population of Ontario (15). Because the life expectancy in TS is significantly lower than in general population (mostly due to cardiovascular abnormalities), many patients with TS may not survive to the age at which $\mathrm{PBC}$ manifests itself clinically. This figure may therefore be much higher than only 10 -fold.

A recent report (2) demonstrated that $\mathrm{X}$ chromosome monosomy occurred significantly more commonly in patients with PBC than in controls and patients with hepatitis C (in particular, affecting cells involved in adaptive immune reactions). The authors suggest that the deficiency of genes localized to the $\mathrm{X}$ chromosome may predispose to altered immune responses, thus increasing the risk of PBC. Because genetic predisposition to $\mathrm{PBC}$ has been supported by several reports (16), systematic studies, including autoimmune markers in cholestatic patients with TS, may help in the elucidation of the etiology of PBC. 


\section{REFERENCES}

1. Elsheikh M, Dunger DB, Conway GS, Wass JA. Turner's syndrome in adulthood. Endocr Rev 2002;23:120-40.

2. Invernizzi P, Miozzo M, Battezzati PM, et al. Frequency of monosomy $\mathrm{X}$ in women with primary biliary cirrhosis. Lancet 2004;363:533-5.

3. Gravholt CH, Juul S, Naeraa RW, Hansen J. Morbidity in Turner syndrome. J Clin Epidemiol 1998;51:147-58.

4. Sokol L, Stueben ET, Jaikishen JP, Lamarche MB. Turner syndrome associated with acquired von Willebrand disease, primary biliary cirrhosis, and inflammatory bowel disease. Am J Hematol 2002;70:257-9.

5. Gomez Antunez M, Cuenca Carvajal C, Ortiz Vega M, Monteoliva Marguez JE, Gorostiza JR, Filgueia Rubio JS. [Association of primary biliary cirrhosis, Turner's syndrome and chronic myeloid leukemia]. Gastroenterol Hepatol 1997;20:44-5.

6. Ray S, Gibley SG, Mansfield MW. A patient with Turner syndrome, type 2 diabetes and primary biliary cirrhosis. Proceedings of 21st Joint Meeting of British Endocrine Society 2002;43. (Abst)

7. Sylven L, Hagenfeldt K, Brondum-Nielsen K, von Schoultz B. Middle-aged women with Turner's syndrome. Medical status, hormonal treatment and social life. Acta Endocrinol (Copenh) 1991;125:359-65.

8. Bogdanos DP, Baum H, Vergani D. Antimitochondrial and other autoantibodies. Clin Liver Dis 2003;7:759-77.
9. Milkiewicz P, Heathcote J. Can Turner syndrome teach us about the pathogenesis of chronic cholestasis? Hepatology 2004:40:1226-8.

10. Larizza D, Locatelli M, Vitali L, et al. Serum liver enzymes in Turner syndrome. Eur J Pediatr 2000;159:143-8.

11. Price WH. A high incidence of chronic inflammatory bowel disease in patients with Turner's syndrome. J Med Genet 1979;16:263-6.

12. Bonamico M, Pasquino AM, Mariani P, et al. Prevalence and clinical picture of celiac disease in Turner syndrome. J Clin Endocrinol Metab 2002;87:5495-8.

13. Roulot D, Degott C, Chazouilleres O, et al. Vascular involvement of the liver in Turner's syndrome. Hepatology 2004;39:239-47.

14. Mansfield C, Hopfer S, Marteau TM. Termination rates after prenatal diagnosis of Down syndrome, spina bifida, anencephaly, and Turner and Klinefelter syndromes: A systematic literature review. European Concerted Action: DADA (Decision-making After the Diagnosis of a fetal Abnormality). Prenat Diagn 1999;19:808-12.

15. Witt-Sullivan H, Heathcote J, Cauch K, et al. The demography of primary biliary cirrhosis in Ontario, Canada. Hepatology 1990;12:98-105.

16. Jones DE, Donaldson PT. Genetic factors in the pathogenesis of primary biliary cirrhosis. Clin Liver Dis 2003;7:841-64. 


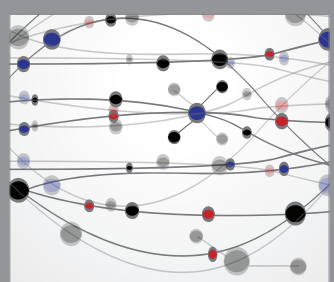

The Scientific World Journal
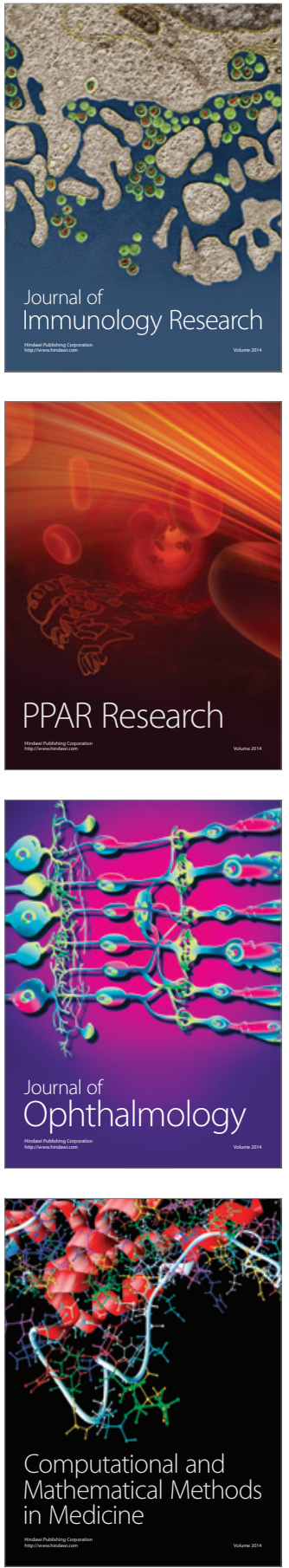

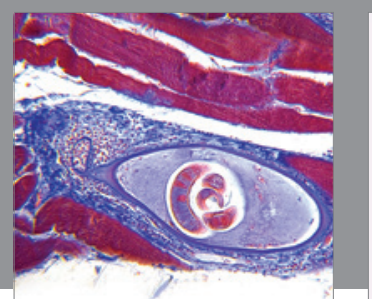

Gastroenterology Research and Practice

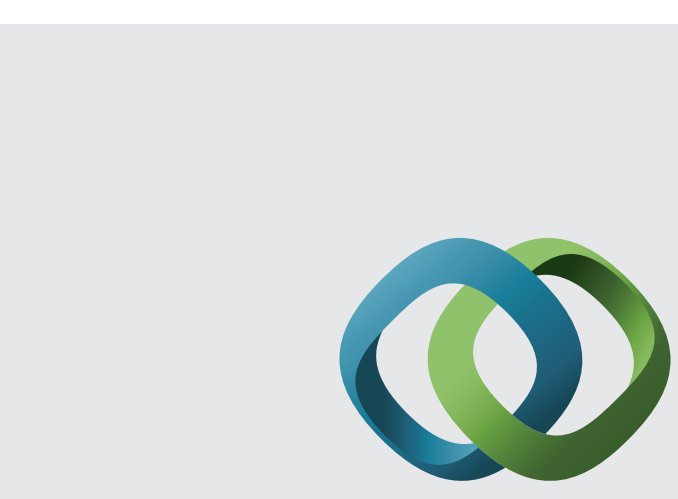

\section{Hindawi}

Submit your manuscripts at

http://www.hindawi.com
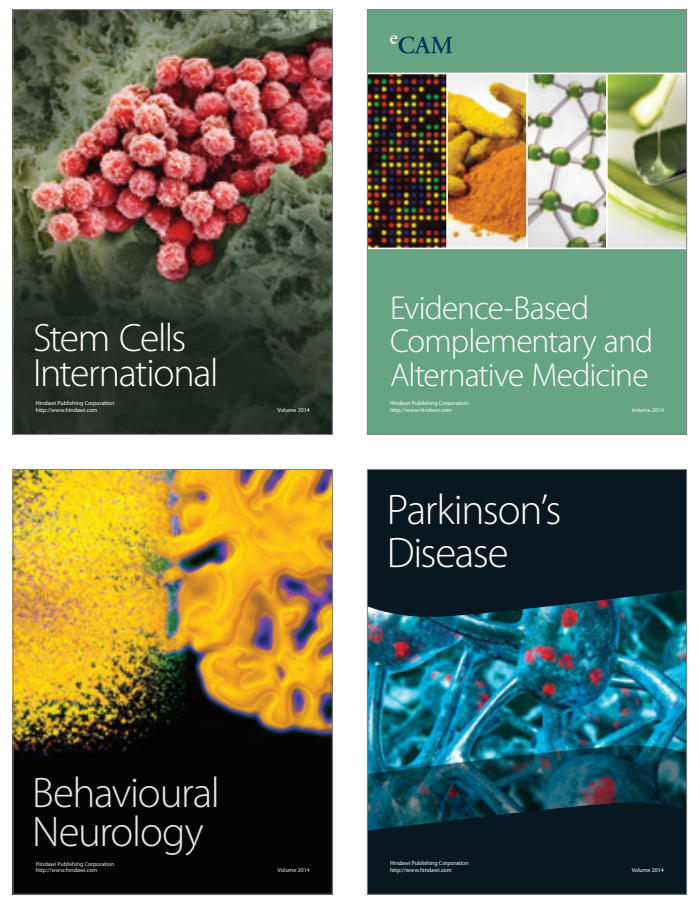
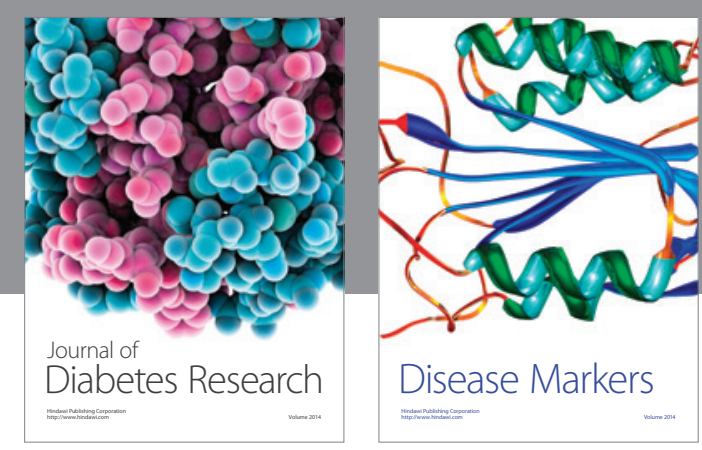

Disease Markers
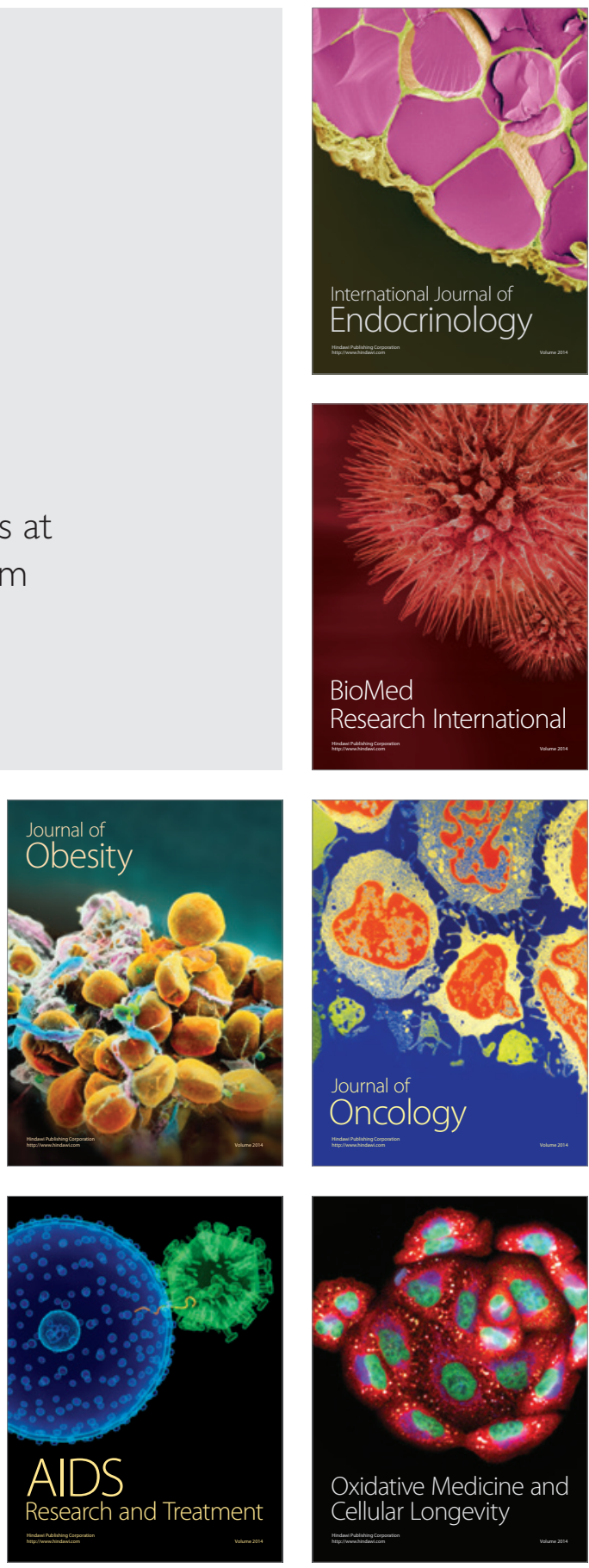